CITY OF CHICAGO - DEPARTMENT OF ENVIRONMENT

\title{
URBAN CONSORTIUM ENERGY TASK FORCE
}

PROJECT SUMMARIES/ABSTRACTS

-

U.S. DEPARTMENT OF ENERGY -

DE-FG02-94CE16091 


\section{DISCLAIMER}

This report was prepared as an account of work sponsored by an agency of the United States Government. Neither the United States Government nor any agency thereof, nor any of their employees, make any warranty, express or implied, or assumes any legal liability or responsibility for the accuracy, completeness, or usefulness of any information, apparatus, product, or process disclosed, or represents that its use would not infringe privately owned rights. Reference herein to any specific commercial product, process, or service by trade name, trademark, manufacturer, or otherwise does not necessarily constitute or imply its endorsement, recommendation, or favoring by the United States Government or any agency thereof. The views and opinions of authors expressed herein do not necessarily state or reflect those of the United States Government or any agency thereof. 


\section{DISCLAIMER}

Portions of this document may be illegible in electronic image products. Images are produced from the best available original document. 


\section{SUMYARY STATEMENT OF WORK FOR CITY/COUNTY PROJECTS}

\section{TASK \#1-22}

\section{UNIT I TRANSPORTATION}

Task \#1 Demonstration and economic analysis of biodiesel in municipal refuse trucks

(Chicago, IL) and marine application

Chicago's examination of biodiesel options in municipal refuse trucks will make use of Midwestern resources, and is potentially transferrable to a range of urban areas in that section of the country. One innovative aspect of Chicago's project is its focus on heavy duty vehicles.

Task \#2 Long Beach Telebusiness Center (Long Beach, CA)

The Long Beach telebusiness project will build on past UCETF work and the increased emphasis on telecommuting, and is expected to be highly transferrable. The project will focus on means of

evaluating and documenting the success of the center in achieving the goals of telecommuting (congestion mitigation and air quality improvement, alternatives to conventional transportation) while a) so considering issues of worker supervision.

Task \#3 Natural Gas Refueling Option Phase 2 (Houston, TX)

Houston will continue to address the significant infrastructure issues associated with the conversion to CNG, a major barrier to widespread reliance on this alternative fuel.

Task \#4 Electric Conversion of Small Trucks and (Albuquerque, NM) Photovoltaic Charging System Design

Albuquerque will look both at electric vehicle conversions for local needs and the means to utilize photovoltaic recharging systems, particularly relevant in the Southwest. Albuquerque's project will build on the city's prior work on designing a multifuel AFV refueling facility.

$\begin{array}{lll}\text { Task \#5 Emergency Police Vehicle CNG (Toledo, OH) } & \end{array}$

While there has been work in the use of dual fuel vehicles in police operations, Toledo will seek to demonstrate the use of dedicated CNG vehicles as police vehicles. 


\section{RESIDENTIAL-BUILOINGS UNIT}

Task \#6 Habitat for Humanity, South Dade Model (Dade County, FL) Community Project

Dade County continues the UCETF involvement in this important effort to restore the area affected by Hurricane Andrew. An important outcome of this project will be the creation of highly transferrable educational materials. This project complements the Department's Building America initiative, focusing on exemplary homes and alternatives to implement new technologies, and with information outreach activities.

Task \#7 Electronic Thermostats: Apartment Comfort and Energy (Portland, OR).

Portland's project to demonstrate the energy saving potential of electronic thermostats has attracted significant private sector participation and cost sharing. Industry has identified a need for this demonstration which, if successful, will likely spur the widespread use of this technology. It focuses on the challenges to energy conservation in multi-family housing.

Task \#8 Demand Side Management Potential in Public (Memphis, TN) Housing

The Memphis project addresses energy consumption in public housing. The project will identify demand side management potential and develop an energy improvement plan for public housing facilities, along with a financial strategy for implementing the improvement plan. This project should be extremely transferrable, and could function as a pilot project for Federal adoption. The project is in keeping with ongoing DOE-HUD collaboration on public housing.

\section{UTILITY UNIT}

Task \#9 Beyond Lighting DSM: Life After Green (Montgomery Co., MD) Lights

Montgomery County will develop and field test specific innovative building technologies and advanced operating and management practices to go beyond lighting retrofits as a means of reducing the energy consumption of local government building stock. The project is designed to result in a management handbook and tool for analyzing local government options for retrofitting interactive energy systems in buildings. This should be highly transferrable to those jurisdictions ready to take the next steps in building retrofits. 
Santa Barbara County, will implement and test incentive-based energy policies to encourage energy efficiency in a variety of sectors. Elements of the Santa Barbara project will include development of an innovative building review program to reward buildings that exceed state energy requirements; implementing a life cycle costing program for major energy using devices of the local government; implementation of a financing mechanism for energy efficiency improvements in county facilities; and costbenefit analysis based on the use of environmental impact reports of new facilities (i.e., cogeneration plants/natural gas refueling infrastructure) to identify requirements for changes in local regulations. The project's multifaceted approach should produce a variety of transferrable tools -for local governments seeking ways of meeting local responsibilities in such areas as permit issuance and zoning approval in a manner that considers --and rewards -energy efficiency.

Task \#11 Lighting Waste Disposal Task Force: (Louisville/Jefferson Co., KY) A Multi-jurisdictional approach to a significant market barrier

The Louisville/Jefferson County project will examine disposal issues associated with the widespread use of energy efficient lighting systems. While minor studies in this area have been conducted, this project may develop a means to resolve what is a substantial market barrier to widespread adoption of improved lighting practices.

\section{SUSTAINABILITY/INTEGRATED RESOURCES PLANNING UNIT}

Task \#12 Implementing Urban Sustainability-- (San Francisco, CA). Next Step

San Francisco will develop an implementation methodology specifically for sustainable urban policies, by focusing on three model implementation efforts -- a returned savings incentives program, an energy efficient materials purchasing program, and a toxic lighting materials disposal program. (Note the consistency with Louisville/Jefferson County project).

Task \#13 Sustainable Decision Support System (Scottsdale, AZ) $\$ 74,200$

Scottsdale, will develop a sustainable decision support system, designed to enable local decisionmakers to project the future impacts of current energy-related decisions ( 1 and use planning, transportation planning, economic development). 
Task \#14 Stapleton Sustainable Development Project (Denver, Co)

Denver's project at the about-to-be retired Stapleton airport, will seek to identify sustainable development goals at the site to be used in the development of zoning and incentive programs at the facility. The project has significant partnering and offers an opportunity for integration of environmentally sound technologies into this major economic development project.

Task \#15 Forging the Links. Creative partnerships (San Jose, CA) in energy, environment and economic development

San Jose will work to develop partnerships with the private sector focusing on sustainable practices, offering a process for initiating dialogues with local businesses and others to encourage adoption of energy efficient and environmentally friendly products and services. The project's "market push/pul1" methodology will offer both information to industry and business on appropriate energy/environmental technologies and economic benefits.

\section{TECHNOLOGY TRANSFER UNIT}

Task \#16 Sustainable Business Development Workbook (Portland, OR) and Training Programs

Portland will use the highly-successful Businesses for an Environmentally Sustainable Tomorrow (BEST) program as a resource for development of a workbook and training workshops on sustainable business practices.

Task \#17 Employee Trip Coordinator Training (Chicago, IL) Programs

Chicago will develop a training program for employee trip coordinators. The potential market for this program is nationwide, and includes both the public and private sectors, as employers are required under the Clean Air Act or local programs to develop mechanisms to reduce employee commuting trips.

Task \#18 Energy Management Guide for Local (San Francisco, CA) Governments

San Francisco's project is a direct, hands-on peer transfer program, through which the City's extensive expertise in development and implementation of energy programs will be transferred to another California city (San Diego). This program, in addition to directly improving the energy management abilities in San Diego, will provide a transferrable model for the nation, complete with guidebook and workshop format. 
Task \#19 DeveTopment of Standard Specifications (Philadelphia, PA) for LEO Traffic Signals

In a 1993 project, Philadelphia considered and documented the energy saving potential of LED traffic signals." There is significant interest in this new technology application, and Philadelphia will undertake a transfer project to develop standard model specifications for LED traffic signals. The commercialization of this technology could be greatly enhanced by Philadelphia's efforts.

Task \#20 A Site Lighting guide for Vermont (Chittenden County, VT) Municipalities

The Chittenden County Regional -Planning Commission will conduct a project proposed by a number of local jurisdictions in Vermont. The project, to create a site lighting guide for Vermont municipalities, will document applications for specific lighting technologies that can be helpful to a variety of local governments, both large and small.

Task \#21 Performance Update of Sludge Storage (Memphis, TN) Lagoon Biogas Recovery

Memphis will look back at its successful 1991 project analyzing the benefits of biogas recovery from a covered sludge storage lagoon. Given the prevalence of sludge lagoons as a wastewater treatment method around the United States, Memphis's project to conduct a performance update of its project should produce valuable information to demonstrate the value of this approach throughout the nation.

Task \#22 Health Care Cost Reduction Through (Sioux Falls, SD) Telecommuting In A Small Urbanized Area

Sioux Falls will implement a pilot telecommuting program in a small urbanized area. By seeking to develop alternative worksites for medical transcription services, this project seeks to identify a means of reducing health care costs while at the same time achieving the benefits of reduced vehicle miles traveled. A successful program will provide options for expansion to other employers in the area as part of the city's travel demand management program. 


\section{SUMMARY STATEMENT OF WORK FOR CORE PROGRAM TASKS \\ (TASKS \#23-27)}

Task \#23 Technology Transfer and Development

Public Technology, Inc. will provide overall coordination for this task and will conduct some or part of the subtasks; Urban Consortium Energy Task Force member cities and the Rocky Mountain Institute will perform other tasks. Six specific sub-tasks will be conduce:

1) conduct three peer-to-peer exchange teams to give "SWAT" assistance to small and medium size cities implementing energy efficiency measure-4Montgomery Co., Denver, and San Francisco will provide assistance);

2) conduct one regional Clean Air workshop that incorporates results from previous year's workshops (PTI);

3) package UCETF and Rocky Mountain Institute (RMI) products for workshops (PTI and RMI);

4) prepare and place articles and press releases and provide input to DOE city/county fact sheet services;

5) produce a video teleconference on sustainability for communities;

6) Update existing UCETF videos or produce video segment for Government Services Television or for a CD-ROM.

Task \#24 City of Chicago Fiscal and Management Activities

City of Chicago, as the official fiscal agent and the business manager for the Urban Consortium Energy Task Force, shall perform fiscal, administration and management activities including the following:

1) As recipient of the cooperative agreement and as fiscal agent, executes award documents and manages disbursement of funds to program participants, maintains compliance with award rules and regulations, reviews quarterly progress reports and monitors drawdown of funds;

2) processes and executes contracts; contract modifications and amendments;

3) provides liaison with the U.S. DOE headquarters and Chicago Operations Contracts Divisions;

4) distributes the annual Request for Proposals. 
Task \#25 UCETF Chair Overall Programmatic Management and Direction

Provide staff assistance to the chair of the UCETF:

1) assist chair carryout day-to-day programmatic management;

2) assist chair provide overall programmatic and substantive direction;

3) assist chair provide liaison to outside groups to deploy technology transfer and program outreach.

Task \#26 Public Technology, Inc, Sub-Contractor Support

Public Technology, Inc. shall provide management and technical assistance services in support of the UCETF:

1) strategic planning, development of the UCETF workplan;

2) program development including development of the RFP and proposal to DOE and technical support/outreach to new participants;

3) management and administration including administration support to UCETF meetings, preparation of summaries of UCETF activities, and review of final project reports.

Task \#27 Van Ness Feidman Curtis Sub-Contract or Support

1) technical and administrative assistance to the Chair including attendance at UCETF meetings;

2) legislative regulatory implementation status review, especially the Energy Policy Act;

3) support for expanded technology transfer activities; and

4) assistance with the RFP process. 


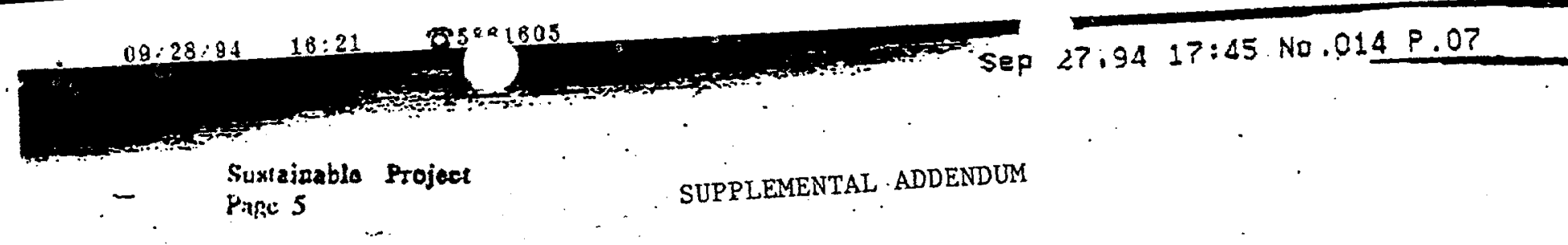

\section{STATEMENT OF WORK}

The following aspects of the sustainable building technical manual and the sustainability case-studies work program are set forth in the takk format with. a timeline for clarity.

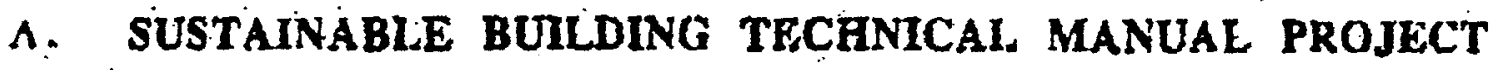

Orerview

The Sustainsbie Building. Technical Manual Project is to develop a tcchinical mannal for public officials, as well as other building owners and operators, that will allow them to put into practice sustainable, or "green" building technologies.

projecl goals are to:

- promote the development, utilization, and commercialization of "green" or sustainable building technologies,

- introduce grcen building technologies to public officials, and other - building owners and managers,

- provide additional resources to public officials to enable them to take the next steps to implement these technologies;

- provide the format to allow tailoring of the technical manual for individual local government to promote successful inclusion of sustainable-building technologies at the local level.

The project will develop a detailed technical manoal for use by institutional/commercial bullding owners and managers and the construction industry to provide guidelines and resources for. sustainable construction and removation practlces. This manual will be based on the conceptrial framework developed by the EPA-fundod Local Government Sustainable Buildings Guidebook. It will provide detailed information on green technologies in the areas of building materials, interior design and furnishings, water conservation, solld waste, and landscaping; construction guidelines; manufacturers and supplicrs; and national sources of technical ussistance for green building practices. The manual will also provide an overview of national and local actions to establish green building codes and standatds. 


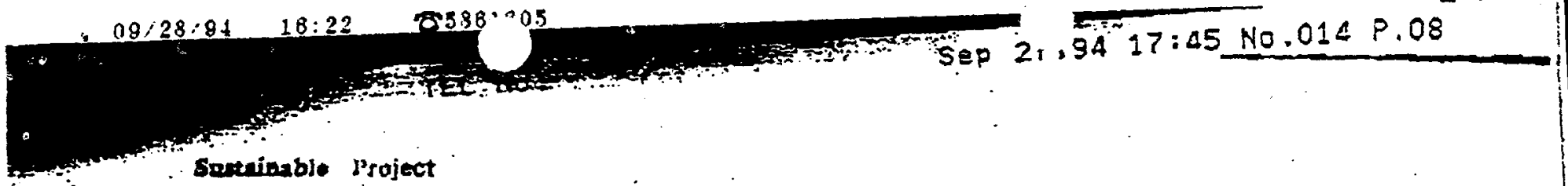

Pase 6

- The technical manual will be designed as a loose-leaf notebook with the Inteni that local governments can adapt or add to the material in the manual to reflect their local and state building codes and standards; and to add local sources of technical assistance and matorials: Austin, Texas, which has developed a technical manual for residential construction, will be involved in the project as a special technical advisor during the writitig and production of the manual. The U.S. Green Building Council (USGBC) will participate in the project as a technical consultant in the design and implementation of this project. An advisory committee of local government officials from the Urban Consortium Task Forces, construction industry. representalives, and federal officials will review the technical manual while it is under production to ensure that the finished docament is technically. accurate, as well as readily applicabie to constroction projects.

\section{Project Tasks. And Timeline}

\begin{tabular}{|c|c|}
\hline Monsh & Products \\
\hline $1-2$ & $\begin{array}{l}\text { Parthers meer to bave initial input into design, } \\
\text { drection, and comtent of mandel. Advisory. } \\
\text { Commutice formed with partwer representatives. }\end{array}$ \\
\hline $2-4$ & Reseurch on manal begins. \\
\hline & $\begin{array}{l}\text { Advisory Committer meets to review } \\
\text { masual ourline and addess issues relased to the } \\
\text { technical materials \& format - Month } 5\end{array}$ \\
\hline $5-7$ & $\begin{array}{l}\text { Research and writing continues with input from Advisory } \\
\text { Commiltee. }\end{array}$ \\
\hline 10 & $\begin{array}{l}\text { Draft document finalized. } \\
\text { Editing and production process. }\end{array}$ \\
\hline 11 & $\begin{array}{l}\text { Initul narketing of mand through parmer networks. } \\
\text { Evaluetion of response to technical manual }\end{array}$ \\
\hline
\end{tabular}

\section{Evaluation Component}

An ovaluation of both the technical manual development and the initial responsc to the manoal's usefulness will be built into the projoct plan. In the short term, project suceess. will be measured by feedback from the advisory committee regarding the effectiveness of the tochnical mannal. Long term project success will be meusured 
Sutuinable Project

7

through an increase in green producis' inclasion into building design, operations, and procurement practices.

DELIVERABLE: A sustainable building tochnical manusl.

Budget

The total project budget for the Sustainable Building Technical Manual Project is $\$ 253,596.00$. Budget details are attached.

\section{B. SUSTAINABLE LOCAL GOVERNMENT CASE STUDIES}

\section{Overview}

Drawing on the extensive local government data bases, a minimum of ten (10) local programs will be selected for case studies. The focus of this project is not simply to identify and describe successful sustainability initiatives, but to identify and evaluate policy instruments, fiscal/revenue instroments, institational configuration, and intergovernmental relationships that support sustainability initiatives at the local level.

- Pollcy Instruments -- Local governments can utilize numerous polioy instruments to achjeve sastainability objectives: direct regulation (bans, inpat controls, consamption controls, price controls, and emission/efflnent controls); fiscal incentives (emission fecs, deposit-refund systems, and various taxes); standards (Icchnology standards, licensing and certification, zoning ordinances); subsidies; direct government expenditures; information provision; oducation; and rechnology demonstration programs. These policy instruments vary in their abillty to achieve specifie sustainability objectives. The proposed case studies will characterizo and evaluate policy instruments utilized to. initiate sustainablity programs.

- Fical \& Revenue Instruments -- Local governments face many issues when determining fiscal and revenue options to support sustainability intiatives. Iocal governments have broad taxing and bonding authority, can issue and recelve grant moneys, assess and charge user and concession fees, issue licenses. teseive federal payments in lieu of taxes, seek privato sector funding, issue patents, participate in intergovernmental 


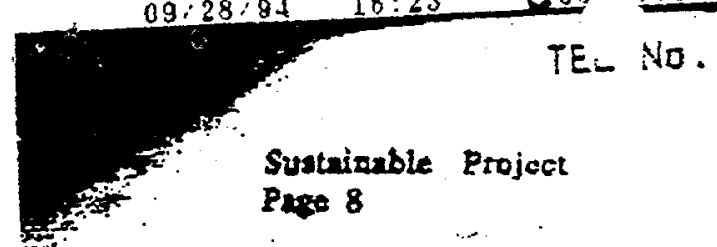

Sep. $\angle 7: 94 \quad 17: 45$ No

- transactions, and establish and administer revolving loan fonds. The proposed case studies will evaluate fiscal and revenue instraments atilized in the case programs and assess overall effectiveness and potential for replication in other cities and counties.

- Institutional Configuration -- Local government units vary significantly with regard to institational configuration, including factors such as governmental structore, administrative procedures, staffing, and managerial roles. There are several general types of Jocal government structure: mayor/council, council/manager, and commisston/executive. Each of these structural types can vary with respect to administrative and procedural factors. Each of these "intitutional packages" is well suited for some activities, less well suited for others. The proposed case study will characterize how the configuration of governmental institutions impacts sustainability initiatives.

- Intergovernmental Relationships -. There are many questions regarding the interaction of federal, state, and local policies, and policy instruments, at the local level. The case study will characterize these interactions, evaluate their effectiveness, and assess potential for similar interactive regimes in ather jurisdictions.

The case stady approach will cnable federal and state agencies to evaluate how their policies and programs affect the activities of local govornments. The case studies will also help local government declaion makers and managers as they consider alternative approaches to meet environmerital sustainability objectives and provide guidance for program implementation. The case studies will help decision makers and managers at all levels to assess (1) which policy instruments lend to be the most effective at the local Jevel; (2) how federal, state, and local policios interact at the local level; (3) the -ffectiveness of federal assistance programs; and (4) gaps in rederal regulatory coveragc that might be addressed at the local level. The case studies will help to increase cooperation between federai, state, and local government onits by providing an analysis of policy and zevenue lastruments and institutional configuration. This type of information will also help accelerate the rate at which energy efficient and sustainable technologies are drawn into the market plece. 
Sustrizable Projecl

Page 9

\section{Products}

As described below; each of the 10 case studies will consider three principal factors for each jurisdiction chosen. A summary and synthesis of the individual studies will be developed to characterize "Lessons Learned" for managors and decision makers at all levels.

1. Description of Local Initiative \& Results - This profile will characterize issues which lead to specific initiatives, program objectives, and describe current statas and planned future activities. The profile will provide a description of the initlative, including a detailed profile of the activity or program and a description of program results. especially physical changes in energy use, pollution, or environmental impacts. The profile will also describe key stakeholders involved in dellberations and program planning.

2. Characterizalion of Local Context - Step two will be to develop a thorough description of the municipality including institutional siructure and procedures, relevant policy instruments, and fiscal/revenue instraments. Particular emphasis will be placed on administrative actions, policy instruments, institutional changes, or fiscal/revenue augmentations needed to sccomplish the initiative. The heart of each case study will be an analysis of the policy, institutional, and fiscal/revenue tools used to initiate and maintain the program. Was the initiative based on fiscal measures or.regulatory controls? How did it mesh with the existing palicy. environment (local, state, federal)? Was. adjudication involved? Questions such as these will help determine the best policy yehicles to employ for local sustainsbllity.

3. Assessment of Replicability - The results of the local activity will be assicssed for opportunities to replicate similar efforts in other cities and/ar counties. "Conditions of Replicability" will be characterized to provide sound reasons for believing that a particular approach is viable in a broader setting. Inis section will also focus on institutional, financial, state and federal policy, or physicallogistical factors that could act to impode replication. The assessmont will also suggest ways to address and overcome the identified barriers. 


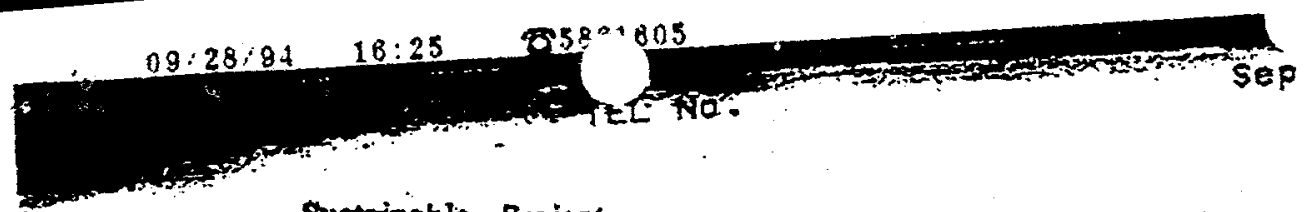

$2 ? .94 \quad 17: 45$ No 0149.12

Suntuinable Projoet

Pux 10

4.- Summary: Lessons Leamed - The case studies will inciude a summary chapter of "Lessons Learned." This chapter will draw from all 10-15 case studies to assess applicable state and federal policies and evaluate the degree to which they support the type of activity described. State and federal policies will also be assessed in terms of their compatibility with local objectives.

\section{Project Tasks And Timeline}

Month Products

1-2 Review available data sources to develop a list of candidate cities and counties. Data bases utilized will at a minimam include PTT's "SOLUTIONS" Technology Sharing Network, 1CLEl's. Urban CO2 Reduction program, NACo's Envisonment, Energy and Land Use Committee, and the RENEW America Environmental Success Index. These comprehensive data bases provide a universe of over 1500 verified programs. An initial scteening process will climinate programs that are clearly inappropriate: limited by physical factors, limited by exorbitant cost, initiared under limiting legal conditions, and so on.

2 .. Identify local government officials to serve as an advisory capacity, drawn from existing Urban Consortium and NACO, and NLC's cities and conntles.

3-4 Develop criteria for selection of cities/counties to be studied. Criteria will focos on the following factors:

- duration of program

- scopo of program

- quentified resplts/impacts

- multi-media impacts.

- cost-effectiveness

- outreach and education.

- replicability potential

Select 10 stady cities/counties. Notify appropriate local officials and provide briefing materials on case study methodology, process, and objectives. 


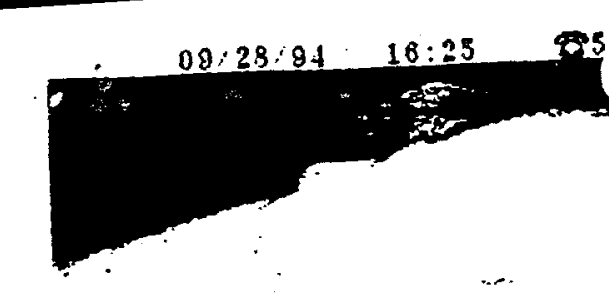

$27: 9417: 45$ No.. -

.5. 5. Data collection. PTL's proven "SOLUTIONS" data base and data management process will be adapted to address the policy/fiscal/revenue/institutional focus of this stody.

7-8 Data analysis. Develop operative construots of data derlved through the survey process. Case studies will rely primarily on diagnostic analyses of poilicy/revenue/institutional constructs, given the objectives of each initiative. Structural/functional and betiavioral analyses of government officials will also be. conducted.

9 Compile, categorize, and synthesize information to be inciuded in the "Lessons Leamed" chapter: Develop initial dsaft "Lessous Learned" chapter.

$10^{\circ}$ Develop initial draft of case studies and distribute to Advisory Groap for peer review. :

11 Revise 10 case studies and pablish final document.

12 Dissemination of results. The 10 case studies will be distributed as bound documents and electronically by reans of PTI's on-line database.

\section{Evaluation Component}

An evaluation component of the project will be designed to jodge both the process for case study development and the effectiveness of the reports in providing replicable models for local goveraments to use as guidelines in the development of sustainablo policies.

DELIVHRABLE: 10 sustainable community case studies. 